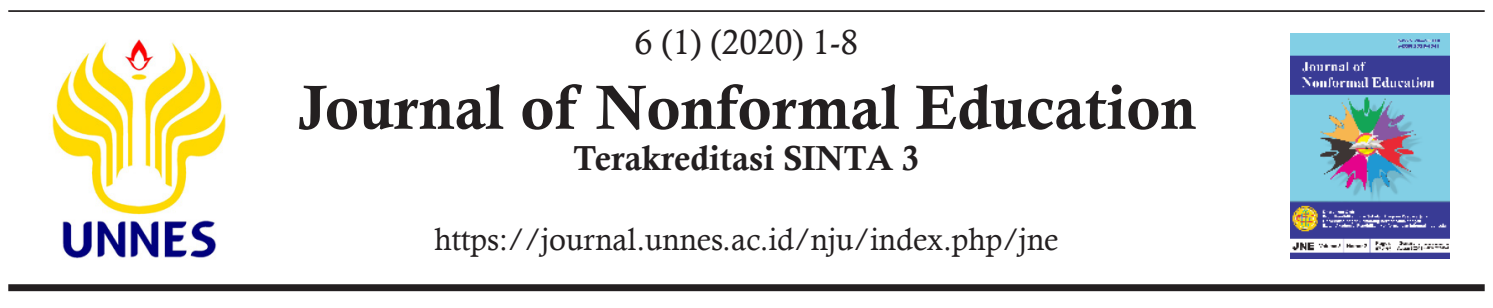

\title{
Entrepreneurship Education for Family Investment Values in Indonesia and the Philippines
}

\author{
Azizah Husin $^{1 凶}$, Yosef $^{1}$, Maria Elvira Asuan ${ }^{2}$, Sri Sumarni ${ }^{1}$, Portio O Surino ${ }^{3}$, \\ Carl O Dellomos ${ }^{3}$
}

DOI: http://dx.doi.org/10.15294/jne.v6i1.22624

${ }^{1}$ Faculty of Teacher Training and Education, Universitas Sriwijaya, Indonesia

${ }^{2}$ Teacher Development PNU Manila, Philippines

${ }^{3}$ Faculty of Teacher Training and Education PNU Manila, Philippines

\section{History Article}

Submitted 22 December 2019 Revised 24 January 2020 Accepted 4 February 2020

\section{Keywords}

entrepreneur education; families in Indonesia; families in Philippines

\begin{abstract}
Education at home is preparing a child for the future even though parents educate their child without a specific goal. But the child gets the knowledge, value, skills, and habits of parental education with love and compassion. The purpose of this research is to know the entrepreneurial education conducted by parents to children in Indonesia and the Philippines. The study was conducted in Indonesia and the Philippines. The population of this research comes from university students in Indonesia and the Philippines. The research respondent is the first semester student to become a respondent, as it is still heavily influenced by family education, the spread of questionnaires using Google forms, where the intended student is 2019 class students to fill the form provided. The maximum sample amount is determined, 216 respondents were acquired for each country. Data analysis techniques use percentages, data is outlined based on the educational aspect given to students by parents in the family. Shows that parents in Indonesia and the Philippines have done their job well. Indonesia acquires higher average value than the Philippines for all components, namely: knowledge, values, habits, and entrepreneurial skills. Overall, it looks how much the average acquisition shows the difference in the results of Indonesia and the Philippines in educating future entrepreneurs by parents. Habituation in children through assignments to do something at home or homework. The value of skills educated by parents in the form of leadership values and the ability to network, communicate, and make decisions quickly. Entrepreneurship education can provide an intensive investment value as long as the child is still in the educational process of his parents at home.
\end{abstract}

Correspondence Author:

E-mail: azizahhusin66@yahoo.co.id
p-ISSN 2442-532X

e-ISSN 2528-4541 


\section{INTRODUCTION}

In the present time the demand for the quality of human resources cannot be taken lightly (Durand, 2011). Globalization provides a broad space for people to have the ability to compete, especially in the world of work (Nayak, 2016). Competition in the world of work to get a job is increasingly complicated when the increase in the number of workforces increases over time (Masitah, 2013). The culture of looking for work is still high in graduates from the world of education. Based on data from (Yudhistira, 2019) there are currently over 600,000 tertiary graduates in Indonesia unemployed or unemployed.

During the past two decades entrepreneurship has become a very active field of research in various social science disciplines and a prominent concern of economic policy (Brandstätter, 2011). Adaptation of economic systems to changing conditions Most of them or 420,000 people from undergraduate education and the rest are diplomas. Open unemployment for university graduates in Indonesia amounts to 398,298 people or $4.31 \%$ of total open unemployment, namely 7,56 people. Not to mention the rate of unemployment in high school graduates is equivalent to not getting a job (Pusparisa, 2019). Based on the facts that there are daily unemployed people are quite large.

The unemployment rate continues to increase in line with the age of work is also increasing while the availability of employment cannot catch up with the population who need work (Masitah, 2013). In addition, the level of competition in the world of work to be very sharp. Then a way is needed to bring the workforce closer together and the world of work. One of the ways is through entrepreneurship education. Since 1995, the Government has issued Presidential Instruction No. 4 of 1995 concerning the National Movement for Promoting and Cultivating Entrepreneurship. This instruction requires all Indonesian people and nation to develop entrepreneurship programs. The amount of entrepreneurship is one of the pillars of the national economy so it must be endeavoured to be continuously improved (Masitah, 2013).

As we know, institutions that provide education are formally schooled, in the community in a non-formal and family manner informally. Education carries out its function of providing knowledge, value, and habituation and skills (Nábělková \& Ratkovská, 2015). Education in the family contains full basic values. This valuefilled content can form the basic character that will determine the quality of the child in the future. The consequences of the development of the times require the ability of a person to be able to compete.

The ability to compete is the ability of a person to compete and be able to win the competition in the right way (honest) and according to the procedure. The person who wins the competition can get the job he gets well. Armed with the ability to compete this is a basic part that is also naturally obtained in education in the family. Does the family have the maximum function of entrepreneurship education and prepare their children to have a brave mentality and be ready to compete and have mental attitude, knowledge, habits and mental attitude to be brave and ready to become entrepreneurs.

Entrepreneurship education in the family is important to make qualified people ready to create jobs (Nicolaides, 2011). If the community has increased the number of entrepreneurs, then it can help create jobs and absorb unemployment. An advanced society is strongly supported by the results of education in the family. The number of entrepreneurs will later be determined by education in the family. The child's mental strength and other basic abilities become the basic capital to compete in the business world.

The most important process (critical) is the process of mental building. In the family this mental formation process runs naturally through the application of the functions/roles of parents in children's education. Strong character is the result of good education, because children have formed courage, strong will, skill, independence in the world. From the description above, this study wants to know entrepreneurship education conducted by Indonesian and Philippine families.

The research aims to obtain information on how the implementation of entrepreneurship education in the family is seen from the aspect of knowledge, planting mental attitudes, habits and skills high school students in Indonesia and Philippine. Humans experience development during their lifetime is the process of the length of education that lived throughout his life. Humans are learned for life and experience a process of development.

As for the low value of character includes the value of God's love character, discipline, cooperation, self-reliant, and responsibility (Nuryanto, 2017). There was a Law number 20 year 2003, about the national education system, which reads that national education serves to develop and shape the character and civilization of the nation dignified in order to educate the life of the 
nation, aims to Growing the potential of learners to become human beings who believe and fear to God Almighty, noble, healthy, knowledgeable, capable, creative, independent, and be a democratic citizen and responsible.

Education takes place everywhere while someone understands and takes lessons from each/ many situations available (Marsick, \& Watkins, 2015). Education conducts character building so that someone is independent and qualified (Kirom, 2017). Education is a conscious effort carried out by family, society, and government, through activities of guidance, teaching and training that take place in schools and outside school throughout life, to prepare students to play a role in various environment in the future in the future (Collins, 2019). Education is a conscious effort to change human behaviour both individually and in groups to mature people through teaching and training so that they have the ability to be responsible for all their actions.

The learning process can occur in the family, community, school or outside the school. Education aims to realize human beings who are faithful, devoted, intelligent, physically and mentally healthy, have adequate skills, have noble character, have high awareness and always introspection, responsive to problems, and are able to solve problems well and rationally (Anaduaka, 2013). Character education becomes an important part in generating individuals who possess the noble intellect and character. Character education since launch until now is still applied in educational institutions both formal, non-formal, and informal.

Educational services in order to achieve educational goals include: (1) moral-spiritual education, (2) cultural social education and patriotism, (3) intellectual education, (4) skills education, (5) physical education and (6) entrepreneurial education (Smith \& Petersen, 2006). One of the educational services in order to achieve educational goals is entrepreneur education, Research conducted by (Ningrum, 2017) and (Koriah \& Casmudi, 2019) showed that in general education in the family plays a role in developing children's entrepreneurial spirit, successful entrepreneurship is generally triggered by parents either directly or indirectly.

Most mothers play a role in growing and developing soul's entrepreneurship in children, the invitation of mothers to involve children in entrepreneurial activities makes children to consider entrepreneurship as an option. Understanding entrepreneurship is a creative and innovative ability in creating something new that has benefits for oneself and others and is able to face problems and take advantage of opportunities, entrepreneurship education can be defined as an effort carried out by educational institutions to instil knowledge, values, soul and entrepreneurial attitude to students to equip themselves to be independent, creative and innovative human beings (Tilaar, 2012).

The characteristics of people who are entrepreneurs are: dare to take risks, like a challenge, Have high durability. Have a far ahead vision, always trying to give the best (Wibisono, 2011). The purpose of this research is to know entrepreneurship education in families related to the aspects of knowledge, values, habits, and skills given by parents. The contribution of research is to provide a comparison of entrepreneurship education conducted by families in Indonesia and Filiphina.

\section{METHOD}

This research method uses quantitative descriptive research methods. The study was conducted in Indonesia and the Philippines. The population of this study were from University Students in Indonesia and the Philippines. The research respondents were Students of the University of Sriwijaya, University in Indonesia (Unsri FKIP) and PNU students from the Philippines. The reason for using the first semester students to be respondents, is because this student experienced a transition period from senior high school to the next higher education level. They are still strongly influenced by family education, compared to higher semester students.

The sampling technique uses research instruments developed from the educational aspect of the family. Namely: knowledge, habituation values, and skills and skills. The distribution of the questionnaire was using the Google form, where the intended students were the 2019 class year students to fill in the forms provided. The maximum number of samples is determined, 216 respondents are obtained for each country. The sampling technique used is random sampling. Data analysis techniques using percentages, data are described based on aspects of education provided to students by parents in the family. Overall, it is seen how much the average acquisition shows the differences in the results of Indonesia and the Philippines in educating future entrepreneurs by parents. 


\section{RESULTS AND DISCUSSION}

Entrepreneurship education can change the theoretical aspects of planned behavior in educational programs as it can positively affect the attitudes and behaviors that the perceived control (Letsoalo \& Rankhumise, 2019). Entrepreneurship Pedagogy is the study of the methods and styles of teaching entrepreneurship. Different approaches are involved and these have to do with the different models that are used in teaching and communicating entrepreneurship education in our schools, institutions, organisations and society (Moses \& Mosunmola, 2014). Although the course in entrepreneurship education, primarily, it is far from achieving desirable maturity either in theory or practice. International project management and their successful completion depend on more complex factors when compared to national, Regional or local scale projects (Anishchenko, et al., 2020).

Entrepreneurship is a process of identifying, evaluating and using opportunities to modernize or create new goods and services in order to make a profit. The presence of entrepreneurship education is one of the factors for the success of entrepreneurial activities itself (Mutalimov, et al., 2020). Entrepreneurship education involves mastering professional competencies, a presence that is a sustained competitive advantage of an entrepreneur (Moses \& Mosunmola, 2014). In the world of entrepreneurship education campuses for students also need to be considered.

The objective of entrepreneurial education is to encourage and create new entrepreneurs backed by the business and industry, business partners and related agencies, so as to create new jobs/businesses or pioneer existing business opportunities, instill mindsets (mindset) and attitude entrepreneurial, provide knowledge of entrepreneurship, provide skills in the field of goods production/service, and practice entrepreneurial skills to students through practice Entrepreneurial (Hidayat, 2017). Entrepreneurial education is guided by parents to pioneer efforts in accordance with the skills gained to produce goods and services to meet the needs of the market.

Overall from Table 1 it can be seen that the difference in average acquisition for all aspects is not much different. This can be seen in the acquisition of the respective average figures, namely for Indonesia averaging 3.37 for the Philippines 3.22. The average difference of 0.15 points. The aspect of education on entrepreneurship knowledge in Indonesia obtained an average of 3.17 and the Philippines 3.01.
Table 1. Recapitulation of entrepreneurship education in families in Indonesia and the Philippines

\begin{tabular}{|c|c|c|c|c|}
\hline \multirow{2}{*}{$\begin{array}{l}\text { Entrepreneurship } \\
\text { Education }\end{array}$} & \multicolumn{2}{|c|}{ Indonesia } & \multicolumn{2}{|c|}{ Philippine } \\
\hline & Mean & SD & Mean & $\mathrm{SD}$ \\
\hline $\begin{array}{l}\text { Knowledge } \\
\text { obtained from } \\
\text { parents about } \\
\text { entrepreneurship } \\
\text { education }\end{array}$ & 3.17 & 0.43 & 3.01 & 0.57 \\
\hline $\begin{array}{l}\text { The values that } \\
\text { are instilled from } \\
\text { parents about } \\
\text { entrepreneurship } \\
\text { education }\end{array}$ & 3.64 & 0.61 & 3.61 & 0.45 \\
\hline $\begin{array}{l}\text { Entrepreneurship } \\
\text { education habits } \\
\text { that are facilitated } \\
\text { by parents }\end{array}$ & 3.32 & 0.57 & 3.04 & 0.45 \\
\hline $\begin{array}{l}\text { Entrepreneur- } \\
\text { ship education } \\
\text { skills are obtained } \\
\text { through parental } \\
\text { guidance }\end{array}$ & 3.36 & 0.41 & 3.31 & 0.50 \\
\hline Average & 3.37 & & 3.22 & \\
\hline
\end{tabular}

Indonesia is slightly higher than the Philippines with a difference of only 0.16 points. Thus, entrepreneurship education in the family between Indonesia and the Philippines are carried out by parents with frequent categories. A significant difference in the average number in the aspect of habituation of children there is a difference in numbers of 0.28 points. Indonesia received an average of 3.32 and an average Filipino of 3.04. This difference shows that Indonesian parents are significantly more educated in habituation than do Filipino families. From Table 1 it can be seen that the educational aspects of entrepreneurial values and the aspects of entrepreneurial skills and skills have almost no difference between Indonesia and the Philippines.

The difference in numbers is only 0.3 points for aspects of entrepreneurial values and 0.5 points for aspects of entrepreneurial skills and skills. Parents in Indonesia and the Philippines Means carry out education for both aspects with the same category that is often. The acquisition of a good average score for the aspects of education values and for aspects of skills and skills in both countries. The highest scores for the two countries in the aspect of educational values are Indonesia 3.64 and Philippines 3.61. This score is equally high. This means that value education 
is very often done by parents, where value education is the basis for children to have an entrepreneurial mental attitude.

Based on the calculation of the scores obtained, it can be concluded that the results obtained by both families in Indonesia and the Philippines in the category often. So, parents, both Indonesians and Filipinos do the same thing, often educating children for entrepreneurship education. Both countries through education in the family see the need to provide a strong basic education. Strong basic education turns out to be very closely related to the preparation of future generations to be able to be entrepreneurs. Parents prepare their children as future generations by providing knowledge related to understanding work and the facts of the world of work, choices, managing finances, the importance of saving.

Parents provide positive basic values, which are very much needed for an entrepreneur namely: believe in, strong willed, responsible, honest, independent, and not easy to give up, forward-looking. Parents teach children to get used to the difficulties of life, work hard, simplicity, get used to positive things and do positive things. Parents also provide leadership education, communication skills, creative and innovative.

The family is an informal educational environment. Informal education is learning to belong to a community of practice, which is dependent on the practices, norms, and values of that community: characteristics commonly associated with formal education (Smith \& Phillips, 2015). The family is built with the relationship of parental love. Family education as part of the national education pathway certainly provides a major role in national development. The family as a leading guard in educating the child in the outdoor en- vironment (informal education) and being the foundation (Pradikto \& Sofino, 2019).

As an educational institution, relationships that are built in the family are a link of education and parental love. So that the education carried out flows by itself with the hope that children will become qualified, independent, moral and beneficial people. Parents also take responsibility naturally by carrying out the task of transferring knowledge, values, skills and basic skills. Families have an economic function viewed from the perspective of entrepreneurship.

The economic function of the family in this case apart from being a learning skill directly from the family business both in production and service businesses, the family also plays a role in conducting basic education that is very much related to forming entrepreneurial people in the future. What is taught by parents is the basic provision that if developed by a child can be a quality person, including is to be an entrepreneur. In line with the results of research by (Sari, 2017) and (Raposo \& Paço, 2011) the family have implemented train children to form an Entrepreneurial Attitude.

Naturally, Parents do basic education and learning how later children value or do something of economic value, teaching children to save money and grow an entrepreneurial spirit. This will make them able to be smart in managing their finances such as the introduction of value for money and saving behaviour (Margaretha \& Pambudhi, 2015). And how to respect money, manage finances. In the end the child will have a mental attitude that is not wasteful/ thrifty. Parents explain about a little money but enough with a lot of money if it cannot be managed, then it is not enough or runs out without benefits.

Parents explain about how to deal with financial difficulties, by saving, how to make enough money given, the importance of saving money and saving for the future. Besides parents' education about finance is not to give children excessive money, always control the child's spending and how much his needs are good for transportation, food, clothing, credit, accessories, etc. Parents teach the principle of saving money with a little proverb to be a little hill and save now to get rich or have fun later.

Parents explain to children about the difficulty of finding work. If they are unable to create their own jobs, the unemployment rate will increase (Izzah, 2015). Explanation from parents leads to the breadth of children's insight into the phenomenon of the world of work that the class must face. For this reason, parents need to be introduced so that children know their strengths and weaknesses. With the aim that children can move forward to adjust the business to the interests of talents and abilities, and children can take advantage of the potential of surrounding resources. Parents explain the importance of working hard. No halal work is obtained without working hard.

In families, education is full of values. The values educated by parents are closely related to morals, namely honesty, responsibility, hard work, saving, simple living, respecting time, never giving up, and others. Value-laden education is education given in the family by parents based on a bond of love, high moral responsibility and quality children's expectations, so that they can live decent, prosperous and happy lives. All of that is the basis of the natural calling of children's education. 
Parents teach in the family about good values for the children's life later. Investment value will be intensive as long as the child is still in the education process of his parents at home. These values if internalized children, greatly affect the provision of children's entrepreneurial mental attitude. Values as the basis for forming the character of children to become disciplined beings, respect the time.

Character development is a development related to the rules and conventions of what humans are supposed to do in their interactions with others. Children learn to understand about which behaviors are good and the bad, the workable and the unworkable so that he can apply it in daily life (Nurhalim, 2017). The value of honesty, independence, responsibility, persistence, tenacity and never give up. And values and relate to resay gratitude.

Relation to the entrepreneurial mental attitude of this value as a foundation for stepping in the field of entrepreneurship. The independent soul brings forth the originality of ideas, processes and results having positive values leads to positive behaviour. Children who has a responsible attitude, it will be good work he is holding. If the child is responsible for his work, shows he has understood what was entrusted to him. Later if he becomes an entrepreneur, he will be reliable. His work will avoid negligence. There is an element of control over efforts to achieve success/ achieve goals.

How to instil values through examples, advice, and the prohibition, reprimand, reprimand, warning, award and punishment (Husin, 2019). All of those are used according to the conditions of the child and parents and the nature of the parents and children. The process of transferring this value between parents to child when faced with a matter relating to the value being taught, or it can also be conveyed that the value is the basis that must be given by parents even though it is not in a situation that matches the object. Parents convey only about good values. Explain, what is more if the child internalizes these values in his life. Later when he is faced with the choice to enter the workforce, this is the basis for the business, although not bound by the situation. Parent teach their children to be responsible if they do something. Parents advise their children to be independent do not depend on others, so that later children and adults know how to manage their duties and responsibilities.

Children are educated at home with habituation to become their daily behaviour. Habit in the house is a continuation of advice, explana- tions, and delivery of information from parents about something that is considered good. Habituation is a parent's effort in educating children by controlling the child's behaviour and monitoring the child's behaviour until it is done routinely so that what is conveyed, told or ordered, becomes part of the child's life (Husin, 2019). For example, accustomed to getting up early in the morning, children can benefit not late, have breakfast, have time to check the need for school, clean themselves/ take a bath properly, calm mind because it is not late for school. By getting used to helping parents' work, children get the skills to do homework or other parental work. Children become skilled at work that is taught/ accustomed.

Later, when they enter the workforce, they will be easier to adjust to various types of work, both work that requires a lot of thinking or physical work or both. Adaptation of children to their work is more flexible. Usually workers like this are more agile at work, and not easy to complain when work gets heavier. With work skills, children are used to facing the world of work. In the family parents educate their children to be creative.

The way parents educate children to be creative is by guiding, giving trust, educating democratically, not dominated by pressure and coercion, positive communication and an atmosphere of affection (Suryana, 2016). Social skills are needed for an entrepreneur. An entrepreneur needs a lot of relationships so that his business is easier to develop. In addition to being proficient in leading, it also takes skills in making decisions. Because making decisions is the result of thinking that produces good or bad evaluations/ assessments, efficient or inefficient, necessary or unnecessary continued, etc.

After that someone decides on something, then next takes action after that. Skills regarding the ability of a person who moves his limbs significantly against an object/ activity that is done/ being studied. Since childhood, children are given the opportunity to do the work of their parents. For example, boy repairing electricity, repairing a leaky roof or a broken door handle.

Based on the results of the research, (Wahyuningsih \& Ulfah, 2016) it was concluded that the family has a positive influence to foster children's interest in entrepreneurship. Families become informal educators to make a strong generation of children. have the knowledge, values, habits, and skills to face challenges in the world of work Marine education has an important role in preparing human resources to enter the business world. 


\section{CONCLUSION}

Entrepreneurship education obtained by children from education in the family is largely determined by the provision of basic education in the family. Education in the family contains knowledge, values, habits, skills and life skills. All of that is general basic education for later life. Entrepreneurial knowledge is related to parents' explanations about the world of work, job choices, job challenge information, managing finances, the importance of saving. The underlying values that are closely related to entrepreneurship are the values of independence, trustworthiness, responsibility, discipline. Habituation in children through assignments to do something at home or homework. The value of skills educated by parents in the form of leadership values and the ability to network, communicate, and make decisions quickly. Average yields between Indonesia and the Philippines are not much different. In general, parents in both countries have done basic education in all aspects.

\section{REFERENCES}

Anaduaka, U. S. (2013). the Universal Basic Education (Ube) Programme in Nigeria: Proble Ms and Prospects. Jorind Ii, 53(9), 1689-1699. https:// doi.org/10.1017/CBO9781107415324.004

Anishchenko, V., Nikolaevskaya, O., Bielialov, T., Koba, A., \& Gumenyuk, T. (2020). Entrepreneurship Education for The Development of International Communications of Project Managers. Journal of Entrepreneurship Education, 23(1), 1-8.

Brandstätter, H. (2011). Personality aspects of entrepreneurship: A look at five meta-analyses. Personality and Individual Differences, 51(3), 222-230. https://doi.org/10.1016/j.paid.2010.07.007

Collins, R. (2019). The credential society: An historical sociology of education and stratification. Columbia University Press.

Durand, T. M. (2011). Latina mothers' cultural beliefs about their children, parental roles, and education: Implications for effective and empowering home-school partnerships. Urban Review, 43(2), 255-278. https://doi.org/10.1007/s11256-010 $-0167-5$

Hidayat, D. (2017). Pengelolaan Pembelajaran Berbasis Kewirausahaan Masyarakat Program Kejar Paket C. Journal of Nonformal Education, 3(1), 1-10. https://doi.org/10.15294/jne.v3i1.8727

Husin, A. (2019). Planting Values for Saving Groundwater through Family Education. Journal of Environmental Protection, 10(05), 595-600. https:// doi.org/10.4236/jep.2019.105034

Izzah, N. (2015). Analisis Dampak Kenaikan Upah Minimum Provinsi, Terhadap Tingkat Pen- gangguran dan Tingkat Partisipasi Angkatan Kerja. Trasparansi: Jurnal Ilmiah Ilmu Administrasi, 7(2), '156-170. https://doi.org/10.1017/ CBO9781107415324.004

Kirom, A. (2017). Peran Guru Dan Peserta Didik Dalam Proses Pembelajaran Berbasis Multikultural. Al Murabbi, 3(1), 69-80. Retrieved from http://jurnal.yudharta.ac.id/v2/index.php/ pai/article/view/893

Koriah, S. \& Casmudi, P. I. (2019). Enterpreneurship Siswi Sekolah Menengah Kejuruan Negeri 2 Balikpapan pada Bisnis Online Shop. Jurnal Edueco, 2(1), 57-66.

Letsoalo, M. E., \& Rankhumise, E. M. (2019). Students' Entrepreneurial Intentions at Two South African Universities Maupi. Journal of Entrepreneurship Education, 23(1), 1-14.

Moses, L. C., \& Mosunmola, A. (2014). Entrepreneurship curriculum and pedagogical challenges in captivating students' interest towards entrepreneurship education. Research Journal of Economics\&Business Studies, 4(1), 1-11.

Margaretha, F., \& Pambudhi, R. A. (2015). Tingkat Literasi Keuangan Pada Mahasiswa S-1. Jurnal Manajemen dan Kewirausahaan, 17(1), 76-85. https://doi.org/10.9744/jmk.17.1.76

Marsick, V., \& Watkins, K. (2015). Informal and Incidental Learning in the Workplace. London: Routledge Revivals. https://doi.org/https://doi. org/10.4324/9781315715926

Masitah, D. (2013). Kewirausahaan Mahasiswa Pendidikan Ekonomi Angkatan Tahun 2009-2010 Fakultas Ekonomi Universitas Negeri Surabaya.

Mutalimov, V., Volkovitckaia, G., Buymov, A., Syzdykov, S., \& Stepanova, D. (2020). Entrepreneurship Education: Start-Up as A Tool For Actualizing Student's Professional Competencies. Journal of Entrepreneurship Education, 23(1), $1-13$.

Nábělková, E., \& Ratkovská, J. (2015). Academic procrastination and factors contributing to its overcoming. New Educational Review, 39(1), 107-118. https://doi.org/10.15804/tner.2015.39.1.09

Nayak, A. (2016). Race, place and globalization: Youth cultures in a changing world. New York, United States: Bloomsbury Publishing.

Nicolaides, A. (2011). Entrepreneurship- the role of Higher Education in South Africa. Educational Research, 2(4), 1043-1050.

Ningrum, M. A. (2017). Peran Keluarga dalam Menumbuhkan Jiwa Wirausaha Sejak Usia Dini. Jurnal Pendidikan (Teori Dan Praktik), 2(1), 39. https://doi.org/10.26740/jp.v2n1.p39-43

Nurhalim, K. (2017). Pola Penanaman Nilai-Nilai Moral Religius Di Tkit Arofah 3 Bade Klego Boyolali. Journal of Nonformal Education, 3(1), 53-59. https://doi.org/10.15294/jne. v3i1.8910

Nuryanto, S. (2017). Peningkatan Nilai-Nilai Karakter dengan Metode Mendongeng Cas Cis Cus di Ba Aisyiyah Kaponan 2 Ponorogo. Journal of 
Azizah Husin et al. / Journal of Nonformal Education 6 (1) (2020) 1-8

Nonformal Education, 3(1), 11-20.

Pradikto, B., \& Sofino, S. (2019). Sex Education in Family: Study on Children Living Far Apart with The Family. Journal of Nonformal Education, 5(2), 36-41. https://doi.org/10.15294/jne .v5i2.20786

Pusparisa, Y. (2019). Angka Pengangguran Lulusan Universitas Meningkat. Retrieved May 17, 2019, from https://katadata.co.id/infografik/2019/05/17/angka-pengangguran-lulusan-perguruan-tinggi-meningkat

Raposo, M., \& Paço, A. (2011). Entrepreneurship education : Relationship between education. Psicothema, 23(3), 453-457.

Sari, N. K. K. (2017). Implementation of Problem Based Learning Methods to Improve The Student Learning Outcomes on The Subjects Processing and Serving of Continental Food in SMK N 4 Surakarta. Jurnal Pendidikan Teknik Boga, 1(1) 1-8.

Suryana, D. (2016). Pendidikan Anak Usia Dini: Stimulasi \& Aspek Perkembangan Anak. Jakarta: Kencana Prenada Media.
Smith, K., \& Petersen, J. L. (2006). What Is Educational Entrepreneurship? Educational Entrepreneurship, 1(1), 1-35.

Smith, T. A., \& Phillips, R. (2015). Labouring and Learning. Labouring and Learning, 2(1), 1-8. https://doi.org/10.1007/978-981-4585-97-2

Tilaar, H. A. R. (2012). Pengembangan kreativitas dan entrepreneurship dalam pendidikan nasiona. Jakarta: Buku Kompas.

Wahyuningsih, T., \& Ulfah, M. (2016). Pengaruh Lingkungan Keluarga dan Kepribadian Wirausaha Terhadap Minat Berwirausaha Siswa Kelas XI SMKN Pontianak. Ekonomi Pendidikan, 6(7) 1-13. Retrieved from https://media.neliti. $\mathrm{com} / \mathrm{media} /$ publications/217301-pengaruhlingkungan-keluarga-dan-kepriba.pdf

Wibisono, A. (2011). Pendidikan Kewirausahaan (konsep dan strategi). Yogyakarta: Pustaka Belajar.

Yudhistira, Y. (2019). Angka Pengangguran Lulusan Universitas Meningkat. Retrieved from https:// katadata.co.id/infografik/2019/05/17/angkapengangguran-lulusan-perguruan-tinggi-meningkat 